\title{
WITTGENSTEIN AND MAIMONIDES ON GOD AND THE LIMITS OF LANGUAGE
}

\author{
N. VERBIN
}

Tel Aviv University

\begin{abstract}
The purpose of this paper is to bring together two thinkers that are concerned with the limits of what can be said, Wittgenstein and Maimonides, and to explore the sense of the good life and of the mystical to which their therapeutic linguistic work gives rise. I argue that despite the similarities, two different senses of the "mystical" are brought to light and two different "forms of life" are explicated and recommended. The paper has three parts. In the first part, I discuss certain key components in Wittgenstein's early philosophy and the sense of the mystical to which they give rise. In the second part, I discuss Maimonides' negative theology and its implications for his conception of the via mystica. I end, with a discussion of the relation between the two ideals and its significance.
\end{abstract}

\section{SEEING THE WORLD RIGHTLY IN THE EARLY WITTGENSTEIN}

Wittgenstein describes the ideal toward which he aims to lead his readers in perceptual terms, as involving a right way of seeing. Using the famous metaphor of the ladder, he states:

My propositions are elucidatory in this way: he who understands me finally recognizes them as senseless, when he has climbed out through them, on them, over them. (He must so to speak throw away the ladder, after he has climbed up on it.) He must surmount these propositions; then he sees the world rightly. (T 6.54). ${ }^{1}$

${ }^{1}$ The following abbreviations of Wittgenstein's works will be used within the text: LE: Ludwig Wittgenstein, "Lecture on Ethics", Philosophical Occasions 19121951 (Indianapolis and Cambridge: Hackett Publishing Company, 1993), pp. 37-44; 
Diagnosing the problems of philosophy as resting on "the misunderstanding of the logic of our language", the Tractatus presents itself as providing us a ladder that consists of logical clarifications, through which a limit is drawn "to thinking, or rather - not to thinking, but to the expression of thoughts" (T, p. 27).

The world that the early Wittgenstein constructs is a world that consists of facts, which are determinate concatenations of objects. Objects are the simple elements from which the world is built. Objects, however, are given to us only in their relation to other objects in atomic facts. Wittgenstein emphasizes that, "it is essential to a thing that it can be a constituent part of an atomic fact" (T 2.011). Language and the world have a common logical form by means of which our propositions can represent states of affairs in the world. Names correspond to objects; elementary propositions to atomic facts and complex propositions to complex facts. Complex propositions are truth functions of elementary ones.

Language, for the early Wittgenstein, consists of propositions; it is essentially representational. Thus, what can be said in language, i.e., represented by language, are facts, contingent, insignificant and valueless states of affairs, which can be true or false. What cannot be said or represented by means of language is the logical form that the world and language have in common, by means of which language can represent the world. The world of meaning and sense extends between the elementary proposition and the complex proposition, which is its truth function. A boundary to the "expressions of thought", a boundary to what can be said is, thereby, established.

How can the Tractarian utterances, which are concerned with the logical form that language and the world have in common, by means of which language can represent the world, and which are professedly nonsense, provide us with logical elucidations? How can they draw a limit to the expressions of thought? To put it slightly differently,

NB: Ludwig Wittgenstein, Notebooks 1914-1916 2nd edition Eds. G. H. von Wright and G. E. M. Anscombe, trans. G. E. M. Anscombe (Chicago: University of Chicago Press, 1984); T: Ludwig Wittgenstein, Tractatus Logico-Philosophicus, [1922] trans. C. K. Ogden (London and New York: Routledge and Kegan Paul, 1988); PI: Ludwig Wittgenstein, Philosophical Investigations Trans. G. E. M Anscombe (New York: Macmillan Publishing Co. Inc., 1968). 
given that what is gained by climbing up the Tractarian ladder cannot be understood in terms of the acquisition of certain truths that can be stated in meaningful propositions and given that the purpose of the Tractatus cannot be understood in terms of the acquisition of ineffable non-propositional truths either, how can the Tractatus' admittedly nonsensical utterances bring about any perceptual transformation at all $?^{2}$ And, what exactly is the nature of the perceptual transformation that the Tractatus seeks to bring about? ${ }^{3}$ I propose that we employ the later Wittgenstein's concept of "perspicuous representation" to address the former set of questions, and his distinction between saying and showing to address the latter. I cannot offer, in this context, a detailed argument for the relevance of Wittgenstein's concept of "perspicuous representation" to the Tractatus. I shall merely gesture at the possible advantages that "perspicuous representation" may have, when used as an exegetical tool for approaching the problematic status of Tractarian utterances.

${ }^{2}$ For the "ineffable truths" conception and its variants, see, e.g., P. M. S. Hacker, Insight and Illusion: Themes in the Philosophy of Wittgenstein, revised edition (Oxford: Oxford University Press, 1986); G. E. M. Anscombe, An Introduction to Wittgenstein's Tractatus, (London: Hutchinson, 1971). The fact that, given the Tractarian perspective, there can be no ineffable truths has been recognized by numerous interpreters. See, e.g., Michael Morris and Julian Dodd, "Mysticism and Nonsense in the Tractatus", European Journal of Philosophy 17/2 (2007), pp. 247-276. Appealing to the distinction between "saying" (what cannot be said) and "thinking" or "imagining" (what cannot be said) provides no way out of this difficulty. Given the Tractarian perspective, thinking and imagining is a kind of language. Nothing is, therefore, achieved when we push language back into the head. Thus, there cannot be thoughts or truths or imaginings that cannot be uttered by means of propositions.

${ }^{3}$ The path toward the realization of the ideal of "seeing rightly" and its very fulfillment cannot be understood in propositional terms. Since the path toward the realization of the Tractarian ideal of "seeing rightly" and its very fulfillment cannot be understood in propositional terms, as involving "knowledge that..." philosophers were tempted to characterize it in terms of "knowledge how..." Kremer, adopting the so-called resolute reading of the Tractatus, argues that Tractarian nonsense affords its readers with "knowledge how", which does not necessarily involve propositional knowledge, and is irreducible to "knowledge that". He explicates such "knowledge how" as knowledge how to live. See Michael Kremer, "The Purpose of Tractarian Nonsense" Nous 35/1 (2001), pp. 39-73. As Morris and Dodd point out, since Wittgenstein uses "seeing" and not "knowing", a more accurate analysis of the Tractatus will pay attention to Wittgenstein's selection of words, and construe it in terms of perception rather than in terms of "knowing how". 
The early Wittgenstein believed that our language disguises thought: Language disguises the thought; so that from the form of the clothes one cannot infer the form of the thought they clothe, because the external form of the clothes is constructed with quite another object than to let the form of the body be recognised ( $\mathrm{T} 4.002$ ).

It may seem that the philosophical work of the early Wittgenstein primarily involves undressing the clothing of language to facilitate a clearer view of the genuine body of thinking underlying it. I wish to propose a different, and a more helpful metaphor to describe the Tractarian methodology - that of placing different clothed bodies side by side, thereby bringing to light the diverse relations between the different clothes and the different bodies. This methodology, which was employed by the later Wittgenstein, may shed light on the manner in which nonsense can be illuminating.

In his later philosophy, Wittgenstein emphasizes the significance of finding a "perspicuous representation" by means of "reminders", connecting links or intermediate cases:

A main source of our failure to understand is that we do not command a clear view of the use of our words. - Our grammar is lacking in this sort of perspicuity. A perspicuous representation produces just that understanding which consists in 'seeing connexions.' Hence the importance of finding and inventing intermediate cases. The concept of perspicuous representation is of fundamental significance for us. It earmarks the form of account we give, the way we look at things (Is this a 'Weltanschauung'?) (PI, \$122)

The later Wittgenstein believed that we do not need a general theory concerning "meaning", "thought", "sense" or "nonsense", to acquire understanding of their nature(s). What we need is a method that "puts everything before us, and neither explains nor deduces anything. - Since everything lies open to view there is nothing to explain" (PI, \$126). What we need is a description rather than an (historical, logical, biological, psychological or any other) explanation, which uses external concepts and categories in its attempt to shed light on a particular phenomenon. The description consists of "assembling reminders for a particular purpose" (PI, \$127). Simply by pointing to various facts and by suggesting certain comparisons or analogies, the logical features of various phenomena may be revealed in their complexity, the emptiness of various explanations 
may be exposed, and various philosophical puzzles may be dispelled. We may then acquire a clearer view of the use of our words.

The various types of nonsense in the Tractatus may be seen as "reminders" in a perspicuous representation. Although they cannot be illuminating in virtue of their having a certain sense, as proponents of the so-called resolute reading of the Tractatus argue ${ }^{4}$, they may be illuminating in virtue of their manner of functioning in their specific context, i.e., qua reminders of "nonsense" in a perspicuous representation. When a particular specimen of nonsense is used as a connecting link with another specimen of nonsense, we may be able to see the formal connection between them and, thereby, notice something about sense and nonsense. Such a methodology, in a sense, "undresses" language, revealing its limits.

Anti-metaphysical consequences do not necessarily result from the employment of this methodology. Reminders are always selected from a particular perspective. Since what is judged nonsense in the Tractatus is not empirically self-evident, the Tractarian perspective appears to betray certain philosophical commitments concerning language and its relation to the world. ${ }^{5}$ Our most appropriate source of information concerning what these are is the Tractatus itself and what it contains concerning language, and its conditions. Thus, using "perspicuous representation" as an exegetical tool to address the possibility of illuminating nonsense does not entail an anti-metaphysical reading of the Tractatus; rather, it allows for a reading in which both the picture theory of the proposition and the distinction between saying and showing are endorsed. ${ }^{6}$

\footnotetext{
${ }^{4}$ See, e.g., Cora Diamond, "Frege and Nonsense", The Realist Spirit: Wittgenstein, Philosophy and the Mind (Cambridge, Massachusetts and London: The MIT Press, 1995), pp. 73-93; Cora Diamond, "What Nonsense Might Be", The Realist Spirit: Wittgenstein, Philosophy and the Mind (Cambridge, Massachusetts and London: The MIT Press, 1995), pp. 95-114.

${ }^{5}$ This point is made in Michael Morris and Julian Dodd, "Mysticism and Nonsense in the Tractatus", European Journal of Philosophy 17/2 (2007), pp. 247-276.

6 "Perspicuous representation" and the saying/showing distinction are intrinsically related to one another: "perspicuous representation" is a method of showing something that cannot be said. The Tractatus teaches us that sometimes, it is only by saying what cannot be said that one can show something, i.e., provide a perspicuous representation. To put it slightly differently, in his saying what cannot be said, in his nonsensical utterances, Wittgenstein is showing (i.e., perspicuously representing) "something" concerning
} 
In what follows, I shall, indeed, assume that Wittgenstein is committed to both. ${ }^{7}$

Like other traditional interpreters of the Tractatus, I maintain that Wittgenstein's commitment to the distinction between saying and showing shows itself in the Tractatus and in his correspondence with Russell and others, concerning the Tractatus and its purpose. Wittgenstein states in the Tractatus: "What can be shown cannot be said" (T 4.1212), thereby committing himself to this distinction. A letter to Russell supports that supposition. In a 1919 letter, he stated that the main point of the Tractatus is "the theory of what can be expressed by prop[osition]s, i.e., by language - (and, which comes to the same, what can be thought) and what cannot be expressed by prop[osition]s, but only shown".

By means of the Tractarian distinction between saying and showing Wittgenstein implicitly sets up a corresponding distinction between two different types of seeing: ordinary seeing, which focuses on facts, contingent and insignificant states of affairs, which can be stated in propositions, and investigated by science, and a different type of perception that focuses on that, which shows itself in facts and propositions. This latter form of perception focuses on the logical structure of reality; Wittgenstein characterizes it as "transcendental", "mystical" and of absolute value: "The contemplation of the world sub specie aeterni is its contemplation as a limited whole. The feeling of the world as a limited whole is the mystical feeling" (T 6.45).

"Seeing mystically", "seeing rightly", however, cannot be separated from our ordinary manner of seeing. When we "see mystically", we see

language and its relation to the world. "Perspicuous representation" is used as a way of brining about, what the later Wittgenstein had called, "the dawning of an aspect" (PI, Part II, xi). What is perspicuously represented, or shown, bears directly on the type of life that Wittgenstein considers good or right. As I pointed out, the Tractarian ideal of "seeing rightly" is a perceptual ideal; the good life that follows from the realization of the Tractarian ideal too, is characterized by a certain way of perceiving the world. When it is realized, we turn our gaze in the right direction, and find God or the mystical.

${ }^{7}$ The implications of this methodology to the metaphysical and/or anti-metaphysical components of the Tractatus require further clarification. Much more needs to be said about the application of this methodology to Tractarian nonsense and about the specific manners in which Tractarian nonsense may be exposed as such, as well.

${ }^{8}$ Ludwig Wittgenstein, Cambridge Letters, eds. B. F. McGuiness and G. H. von Wright (Oxford: Blackwell, 1995), p. 124. 
ordinary objects of perception, although we perceive them sub specie aeterni. There is no separate realm of mystical objects that are perceived. Thus, seeing mystically is contemplating that which shows itself in the ordinary and trivial, in the insignificant and banal. It is focusing on an aspect of ordinary states of affairs, perceived by ordinary sense organs.

Such a mode of perception, however, is obscure within the Tractatus. Wittgenstein is aware of the obscurity. He insists that there is an experience of logic; at the same time he states that the term "experience" is inappropriate: "The 'experience' which we need to understand logic is not that such and such is the case, but that something is; but that is no experience." (T 5.552). Logic per se is not a direct object of perception. Logic is not a separate subject matter that is susceptible to a separate examination. Tautologies and contradictions have no meaning and logical constants do not represent. Yet Wittgenstein insists that logic shows itself, that it is seen, experienced through the contingent, through the facts of language and the world, which are per se, of no value and importance.

In his "Lecture on Ethics" of 1929, Wittgenstein mentions three experiences, analogous to the "experience" of logic in their seemingly transcendental non-factual nature. He notes that the term "experience" is unsuitable to characterize them too. He mentions the "experience" of feeling absolutely safe, no matter what happens, the "experience" of wonder at the existence of the world and the "experience" (feeling) of guilt. Wittgenstein recognizes that such experiences present themselves as bearers of absolute value; he nevertheless insists that as bearers of absolute value they cannot amount to genuine experiences, since all experiences are contingent and, as such devoid of value. Wittgenstein, however, affirms the existence of such "experiences", insisting that they cannot be uttered in language:

Now the three experiences, which I have mentioned to you (...) seem to those who have experienced them... to have in some sense an intrinsic absolute value. But when I say they are experiences, surely they are facts... and consequently are describable. And so... I must admit it is nonsense to say they have absolute value. And I will make my point still more acute by saying 'It is the paradox that an experience, a fact, should seem to have supernatural value.' (LE, p. 43) 
Wittgenstein does not give up on either horn of his dilemma, explicitly committing himself to a paradox and depicting our inability to speak of such experiences as a cage. He recognizes that the Tractarian ladder does not lead away from the world, into another supernatural realm but rather takes us back into the straight jacket of language. The dilemma that such "experiences" embody is, therefore, internal to Wittgenstein's early philosophy and must not be explained away. It is only in his later remarks on the seeing of aspects that Wittgenstein was able to allow for, and shed light on such experiences, on such perceptions, insisting on the logical relation between them and our pattern of responses.

Despite these fatal difficulties, a meaningful ideal of "seeing rightly" or "seeing mystically" emerges, in his early thought. The Wittgensteinian ideal has various dimensions: aesthetic, ethical, psychological and religious. I shall briefly remark on each of these dimensions, starting with the aesthetic dimension of Wittgenstein's ideal.

When we "see mystically" we come to see the facts of the world as works of art, be they products of an assembly line, industrial waste or surfaces of exquisite colour and shape. Wittgenstein uses the metaphors of "perceiving together with space and time" and "perceiving with the whole world as background" as explications of this mode of perceiving. In a Notebooks comment from October 1916, he states:

The work of art is the object seen sub specie aeternitatis, and the good life is the world seen sub specie aeternitatis. This is the connection between art and ethics. The usual way of looking at things sees objects as it were from the midst of them, the view sub specie aeternitatis from outside. In such a way that they have the whole world as background. (NB, p. 83)

Such an aesthetic-mystical manner of seeing has ethical and psychological dimensions. Although, like other contingent modes of perception, it is devoid of absolute value, since "in the world everything is as it is and happens as it does happen. In it there is no value - and if there were, it would be of no value "( $\mathrm{T}$ 6.41), seeing the world rightly liberates the observer from the contingency of the world and from the misery that it may bring about. Wittgenstein seems to believe that the person that is capable of seeing the world sub specie aeterni, sees it "with a happy eye" (NB, p. 86). He asks: "Is it the essence of the artistic way of looking at things, that it looks at the world with a happy eye?" (NB, p. 86). He seems 
to believe that when one recognizes the manner in which the sublime and the trivial are intertwined with one another, when one climbs the Tractarian ladder and assents to the world, one transcends the world of facts and the laws that govern them, and finds enduring happiness, which does not result from the fulfilment of one's heart's desires.

The path towards such a conception of "happiness" and its relation to willing can be traced back to a Notebooks comment from July 1916. Wittgenstein ponders:

Is it possible to will good, to will evil, and not to will? Or is only he happy who does not will? To love one's neighbour would mean to will! But can one want and yet not be unhappy if the want does not attain fulfilment? (And this possibility always exists). Is it, according to common conceptions, good to want nothing for one's neighbour, neither good nor evil? And yet in a certain sense it seems that not wanting is the only good. (NB, p. 77)

Slightly later Wittgenstein asks "How can man be happy at all, since he cannot ward off the misery of this world?" (NB, p. 81). "Through a life of knowledge" (NB, p. 81), he answers, stating: "The life of knowledge is the life that is happy in spite of the misery of the world." (NB, p. 81).

The salvific life of knowledge, which is one and the same with the good life, the happy life and the mystical life, cannot be understood in propositional terms. Contingent, insignificant propositional knowledge, which can be uttered in language, does not liberate. Feeling absolutely safe, no matter what, cannot be the result of the acquisition of certain necessary truths about God or the meaning of life, either. Such truths could not be meaningfully stated. Wittgenstein insists that the person who climbs the Tractarian ladder, climbs over his meaningless utterances. Given the meaninglessness of Tractarian utterances, the life of knowledge cannot be characterized in terms of a certain body of doctrine that one comes to acquire. True knowledge, for the early Wittgenstein, is a matter of perception, acquired by a perspicuous representation. Its attainment is the observer's self-transformation. The world remains unaltered. The one who sees it rightly, however, is liberated from it and from the desire to control it.

The person who climbs up the Tractarian ladder and "sees rightly" sees the world as a gestalt picture; he perceives it as a world in which 
"everything is as it is and happens as it does happen", as a world in which "there is no value" (T 6.41), but also as a world in which "There is indeed the inexpressible. This shows itself; it is the mystical" (T 6.522). He is able to see every contingent and insignificant fact as a revelation of the sublime, as a window that reveals the transcendental logical form of the universe, as a miracle. ${ }^{9}$ Reason has an important role to play in the Wittgensteinian logical-spiritual exercises. It is, nevertheless, a preliminary role, directed at perception. Without the perceptual climax, the Tractatus collapses into opaque nonsense.

The transition from reason to perception is clearly evident in another thinker that was concerned with the limits to what can be said. For Maimonides too, the preliminary logical work is designed to culminate in contemplation. I shall now turn to Maimonides' conception of the limit to the expressions of thought and to the perceptual dimension in the religious ideal that he envisages, examining the relationship between knowledge, perception, providence and happiness in his Guide of the Perplexed.

\section{MAIMONIDES ON GOD AND THE LIMITS OF LANGUAGE}

Similarly to the Tractatus, the Guide of the Perplexed too does not aim at conveying a certain set of ineffable truths about God or the sublime. Maimonides insists that such "truths" could be neither thought nor stated in language. Rather, the Guide attempts to bring about a perceptual transformation in the course of which one can "turn his gaze in the right direction" and "see mystically". ${ }^{10}$ The individual of perfect apprehension

\footnotetext{
${ }^{9}$ See Ludwig Wittgenstein, "Lecture on Ethics", in Philosophical Occasions 1912-1951, eds. James Klagge and Alfred Nordmann (Indianapolis and Cambridge: Hackett Publishing Company, 1993); Ludwig Wittgenstein, "Lectures on Religious Belief” in Lectures and Conversations on Aesthetics, Psychology and Religious Belief, ed. Cyril Barrett (Oxford: Basil Blackwell, 1966). For a detailed discussion of seeing aspects in Wittgenstein's philosophy, see N. K. Verbin, "Religious Beliefs and Aspect Seeing", Religious Studies 36 (2000), pp. 1-23.

${ }^{10}$ The expression "turn his gaze in the right direction" is taken from Simone Weil. See Simone Weil, "The Love of God and Affliction", Waiting on God (London: Routledge and Kegan Paul, 1951), pp. 63-78.
} 
must climb through and over the Guide, which is concerned with what cannot be said, surmount its propositions and come to "see rightly"."1

Maimonides attempts to set a limit to what we may say about God. He provides several arguments for the limit that he sets, which have to do with his conceptions of logic, language and their relation to the world. Maimonides believes that an attribute may be one of two things:

It is either the essence of the thing of which it is predicated, in which case it is an explanation of a term... Or the attribute is different from the thing of which it is predicated, being a notion superadded to that thing. This would lead to the conclusion that that attribute is an accident belonging to that essence. $(I / 51, \text { p. } 113)^{12}$

For Maimonides, the essence of a thing, which gives us its definition, provides the explanation of an item in terms of its location in the inventory of beings. It always involves genus and specific difference. It involves reference to the item's causes. Maimonides, thus, concludes:

This kind of attribute should be denied to God according to everybody. For He, may He be exalted, has no causes anterior to Him that are the cause of His existence and by which, in consequence, He is defined. For this reason it is well known among all people engaged in speculation, who understand what they say, that God cannot be defined (I/52, pp. 114-115).

An attribute that signifies an essential or accidental quality of an item too, cannot be attributed to God since "if He has a part of an essence, His essence must be composite" (I/52, p. 115); if He has accidental qualities superadded to His essence "He would be a substratum of accidents" I/52,

${ }^{11}$ The mystical interpretation of Maimonides' Guide of the Perplexed is the minority interpretation. For a prominent proponent of this interpretation, see David R. Blumenthal, Philosophic Mysticism: Studies in Rational Religion (Ramat Gan: Bar Ilan University Press, 2006). Blumenthal characterizes the post-rationalist phase in Maimonides' Guide as "philosophic mysticism". He states: "Reason is the way to post-rational experience" (p. 40) and "Philosophy ... is the prelude to religious experience..." (p. 41). For more on the history of the Guide's mystical interpretation, see Chapter 1 of Blumenthal's Philosophic Mysticism. See also Menachem Lorberbaum, Dazzled by Beauty: Theology as Poetics in Hispanic Jewish Culture (Jerusalem: Ben-Zvi Institute, 2011), [in Hebrew] p. 33 fn 74.

${ }^{12}$ All references within the text to the Guide of the Perplexed are to Moses Maimonides, The Guide of the Perplexed, trans. Shlomo Pines (Chicago: University of Chicago Press, 1963). 
p. 15) and as such composite and changing. The most central types of predication are thereby rejected. ${ }^{13}$ God cannot be defined. Neither essential nor accidental attributes can be ascribed to Him.

As a faithful Jew, committed to Scripture, Maimonides had to contend with the seemingly positive information that Scripture contains about God's nature and actions. Maimonides insists that all biblical attributes (including "existence") apply to God in a completely equivocal manner:

Similarly the terms "knowledge", "power", "will" and "life", as applied to Him, may He be exalted, and to those possessing knowledge, power, will and life, are purely equivocal, so that their meaning when they are predicated of Him is in no way like their meaning in other applications. Do not deem that they are used amphibolously. For when terms are used amphibolously they are predicated of two things between which there is a likeness in respect of some notion... Accordingly ... the meaning of the qualificative attributions ascribed to Him and the meaning of the attributions known to us have nothing in common in any respect or in any mode; these attributions have in common only the name and nothing else (I/ 56, p. 131).

This austere view concerning religious language appears to be somewhat modified. Maimonides interprets Scripture's references to God's nature as references to His manner of acting, thereby allowing "attributes of action". According to Maimonides, "Every attribute that is found in the books of the deity, may He be exalted, is ... an attribute of His action and not an attribute of His essence..." (I/53, p. 121). The seemingly positive depictions of God's nature in the bible are not to be taken at face value.

Since Maimonides also denies the application of relational attributes to God, insisting that God cannot be related to a time or a place, his "attributes of action" cannot and, indeed, do not refer to God's own manner of acting in the world. ${ }^{14}$ By "attributes of action", Maimonides means our human and perspectival tendency to interpret and describe

\footnotetext{
${ }^{13}$ Maimonides also discusses relational predication, involving, e.g., an item's relation to a particular place or a particular time. He denies a relation between God and the world, thereby denying relational predication too. He, nevertheless, views relational predication as less problematic since "it does not entail the positing of a multiplicity of eternal things or the positing of alteration taking place in His essence..." (I/52, p. 118).

${ }^{14}$ See The Guide of the Perplexed I/52
} 
certain worldly realia as effects, brought about by an agent. When we perceive embryos of living beings and the manners in which they are cared for by their caregivers, we tend to say of God that He is merciful. When we perceive calamities annihilating whole tribes or regions, exterminating both young and old, we tend to say that God is jealous and avenging. Maimonides insists, however, that no conclusions concerning God's nature can be drawn, on the basis of what we tend to identify as the effects of His agency.

Given the dangerous ramifications of the use of "attributes of action", namely, the temptation to draw certain conclusions concerning the causal agent's essence from discernable mundane states (conceived of as effects) Maimonides calls for further purification of our idea of God. He calls for negating in thought and speech what God is not:

Know that the description of God, may He be cherished and exalted, by means of negations is the correct description - a description that is not affected by an indulgence in facile language and does not imply any deficiency with respect to God in general or in any particular mode (I/58, p. 134).

Maimonides' negative theology introduces a new "language game" into the life of faith. We do not merely negate various attributes (deficiencies) when using his via negativa, stating, for example, that God is not many, or that God is not finite. We also deny the appropriateness of applying attributes, any attribute whatsoever, to God. His via negativa involves double negations that cannot be replaced by positive utterances. It involves double negations that undo themselves. His via negativa suggests that it is not possible to know God's nature, to entertain thoughts and utter statements about Him:

As everyone is aware that it is not possible, except through negation, to achieve an apprehension of that which is in our power to apprehend and that, on the other hand, negation does not give knowledge in any respect of the true reality of the thing with regard to which the particular matter in question is negated - all men, those of the past and those of the future, affirm clearly that God, may He be exalted, cannot be apprehended by the intellects, and that none but He Himself can apprehend what $\mathrm{He}$ is, and that apprehension of Him consists in the inability to attain the ultimate term in apprehending Him (I/59, p. 139). 
Maimonides' via negativa, therefore, culminates in silence:

The most apt phrase concerning this subject is the dictum occurring in the Psalms, Silence is praise to Thee, which interpreted signifies: silence with regard to You is praise (I/59, p. 139).

Maimonides, however, was not silent, nor did he make do with negative statements only. What is the status of those utterances of the Guide, in which Maimonides makes various statements that betray his underlying commitments concerning God's nature: His impassibility, simplicity, unity etc., and which play a part in his argumentation? Are we to view such utterances as false, or are we to judge them meaningless?

Acknowledging the resemblance between Maimonides and the early Wittgenstein, Seeskin maintains that Maimonides does not perceive his own positive utterances about God as nonsense:

In some respects, Maimonides' view of language resembles the one expressed by Wittgenstein at the end of the Tractatus... Obviously Maimonides would not say that every claim we make about God is nonsensical. But he would say that the claims we make about God are best understood as steps on the way to something higher: a perspective from which we see that strictly speaking nothing we say about God can be true. After reflecting on the deficiencies of religious language, Maimonides also encourages the reader to pass over the subject in silence, quoting Psalm 65:2: 'Silence is praise to thee.. ${ }^{15}$

It is far from obvious that "Maimonides would not say that every claim we make about God is nonsensical". ${ }^{16}$ If we take seriously what Maimonides claims about the radical difference between God and the world, which entails that even "existence" cannot be attributed to God, then the statements of the Guide, cannot be merely false. Their failure, and the failure of each and every utterance about God (if it is to be understood as truly about $\mathrm{God}$ ) is categorical and, as such, deeper than the failure of mere falsity. The predicates by means of which we describe the things of this world cannot, in principle, apply to God. Forcing God and our

\footnotetext{
${ }^{15}$ Kenneth Seeskin, Searching for a Distant God: The Legacy of Maimonides (New York and Oxford: Oxford University Press, 2000), p. 35.

${ }^{16}$ Ibid.
} 
human predicates together in a single utterance is not merely false; it is incoherent nonsense.

Similarly to Wittgenstein's Tractatus, such nonsense plays a pedagogical role in the Guide. It is "illuminating nonsense". Maimonides calls us to use his "illuminating nonsense" as a ladder, to climb over and discard. Discarding the ladder is, among other things, resisting our desire to speak about God and passing over to silence. The Maimonidean silence, similarly to the Wittgensteinian silence, marks the point at which reason stops, language halts and something new may dawn.

When we realize that we can neither speak about the sublime nor acquire any knowledge of it, when we give up the quest for propositional knowledge about God, and recognize the limits of reason, of thinking and saying, then and only then, may we be able to come to see. At the top of the ladder, beyond propositional knowledge, after reason is used to set its own limits, and undo itself, awaits perception for the philosopher/mystic. Something shows itself; something becomes manifest. Maimonides states that it is a dazzling and beautiful apprehension:

Thus, all the philosophers say: We are dazzled by His beauty, and $\mathrm{He}$ is hidden from us because of the intensity with which He becomes manifest, just as the sun is hidden to eyes that are too weak to apprehend it $(\mathrm{I} / 59, \mathrm{p} .139)$.

Like the perception of aspects, it is a fleeting perception:

Sometimes truth flashes out to us so that we think it is day, and then matter and habit in their various forms conceal it so that we find ourselves again in an obscure night, almost as were at first. (I/Introduction, p. 7)

The Guide aims to cleanse the mind from various mistakes, and prepare it to the flashing of that "dazzling truth". It aims to produce a certain type of seeing. When successful, it produces a life that bears certain distinct characteristics, despite the fleeting nature of the dazzling perceptions. It is a good and happy life. It is also a life that enjoys God's providence. I shall end this section with a few remarks on the relation between "seeing mystically" and God's providence. ${ }^{17}$

\footnotetext{
${ }^{17}$ It may appear that Maimonides' discussion of divine providence is related to the workings of the intellect rather than to perception. Maimonides' description of the climactic moment of the deaths of Moses, Aaron and Miriam reveals that providence too, is a matter of non-propositional "knowledge".
} 
Similarly to Wittgenstein, for Maimonides too the capacity to go beyond propositional knowledge and "see mystically" can liberate us from the contingency of the world, and transform us into free and happy human beings. Maimonides believed that a life characterized by this capacity is a good and happy life. He understood divine providence in terms of that capacity, thereby affirming an internal connection between "divine providence", "happiness", and "apprehension".

There are, however, two conceptions of divine providence in the Guide: providence as protection from all types of physical harm, e.g., hunger, poverty, injury or sickness, and providence as protection from the agony that such ills as poverty, injury or sickness ordinarily bring about, but not necessarily from the ills themselves. Such a contemplative conception of divine providence does not involve divine intervention in the ordinary state of things nor does it guarantee protection against physical harm. In what follows, I shall assume that it is the latter, contemplative conception of divine providence that represents Maimonides' views about God's providence. ${ }^{18}$

Maimonides affirms the existence of divine providence insisting that it proceeds according to the principles of justice. Understanding God's nature as "intellect" and our being created in God's image in terms of our "intellect", Maimonides perceives the nature of God's providence over humanity, too, in terms of the workings of the intellect.

$[\mathrm{P}]$ rovidence can only come from an intelligent being... Accordingly everyone with whom something of this [intellectual] overflow is united will be reached by providence to the extent to which it is reached by intellect (III/17, p. 474).

Divine providence, according to Maimonides "is consequent upon the intellect and attached to it" (III/17, p. 474).

${ }^{18}$ The question of Maimonides' ultimate views concerning the nature of God's providence has troubled his contemporaries too. Shmuel Ibn Tibbon, Maimonides' contemporary and first Hebrew translator, has written to Maimonides asking for clarification concerning Maimonides' theory of providence. He suggested several possible interpretations of Maimonides' views on providence and asked for his judgment concerning the most appropriate. No answer, however, has survived. See Zvi Diesendruck, "Samuel and Moses Ibn Tibbon on Maimonides' Theory of Providence", Hebrew Union College Annual 11 (1936), pp. 341-356. 
This famous Maimonidean principle is explicated in several manners, in the Guide: 1) Maimonides insists that divine providence watches only over the individuals belonging to the human species since only they are endowed with intellect; 2) He insists on a correspondence between the degree of one's intellectual perfection and the degree to which one enjoys God's providence; 3) He maintains that divine providence is absent when the individual's intellect does not focus on God although "its withdrawal then is not like its withdrawal from those who have never had intellectual cognition" (III/51, p. 625), and, 4) Maimonides insists that the nature of the distraction has a bearing upon the nature of the harm that befalls on the one who is distracted. He concludes:

If a man's thought is free from distraction, if he apprehends Him, may He be exalted, in the right way and rejoices in what he apprehends, that individual can never be afflicted with evil of any kind. For he is with God and God is with him. When, however, he abandons Him, may He be exalted, and is thus separated from God and God separated from him, he becomes in consequence of this a target for every evil that may happen to befall him. For the thing that necessarily brings about providence and deliverance from the sea of chance consists in that intellectual overflow (III/51, p. 625).

Providence guarantees deliverance from the sea of chance. When one apprehends the sublime, one is free from the sea of chance and its ills. When one, however, focuses on the contingent and insignificant, when one is immersed in the sea of chance one is, by definition, distracted and separated from God. Such a state is, in and of itself, an undesirable, miserable one, in which the perceiver is vulnerable to the accidents of the world.

Maimonides understands Job's suffering in such a manner, i.e., as manifesting ignorance. In his commentary on Job, Maimonides makes the following statements:

The most marvellous and extraordinary thing about this story is the fact that knowledge is not attributed in it to Job. He is not said to be a wise or a comprehending or an intelligent man. Only moral virtue and righteousness in action are ascribed to him. For if he had been wise, his situation would not have been obscure for him... (III/22, p. 487). 
Job's afflictions do not render divine providence impossible or improbable. Job denied God's providence when he had been unwise. After the divine revelations, after he came to acquire wisdom, after he came to see with his own eyes, to see rightly or mystically, he ceased to complain:

When he knew God with a certain knowledge, he admitted that true happiness, which is the knowledge of the deity, is guaranteed to all who know Him and that a human being cannot be troubled in it by any of all the misfortunes in question. While he had known God only through the traditional stories and not by the way of speculation, Job had imagined that the things thought to be happiness, such as health, wealth, and children, are the ultimate goal. For this reason he fell into such perplexity and said such things as he did (III/23, pp. 492-493).

Realizing that property, good health and social status are insignificant, the Maimonidean sage is not pained by their loss. "Seeing mystically" allows the sage to transcend the world, while remaining susceptible to the laws that govern it. The manner of dying of such a sage too, reveals his intellectual perfection - the sage dies "by a kiss", "by the mouth of God", as the Deuteronomistic text reads. Referring to the manner in which Moses, Aaron and Miriam had died, Maimonides states: "The three of them died in the pleasure of this apprehension [of God] due to the intensity of passionate love." (III/51, p. 628). Maimonides characterizes such a manner of dying as "salvation from death" (III/51, 628). ${ }^{19}$ The sage who receives God's providence to its fullest is wholly protected from the sea of chance, from every type of harm, including death. Nothing can undo him.

What is the nature of the intellectual apprehension of God that guarantees God's providence, protection from the ills of this world and from death itself? Given his discussion of the divine attributes in the first part of the Guide, "intellectual apprehension" cannot be conceived of in terms of propositional knowledge that shows itself in true utterances about God and God's nature. The "supreme pleasure of apprehension due to the intensity of passionate love" ascribed to Moses, Aaron and Miriam clearly marks a state that goes beyond reason and beyond the fruits of reason, i.e., beyond what can be stated in propositions. It involves

\footnotetext{
${ }^{19}$ I am grateful to Ron Margolin who pointed out to me the significance of these statements.
} 
contemplation of the sublime, an experience of something that shows itself, a type of seeing.

Divine providence, for Maimonides, does not involve a deity who intervenes or interferes in the contingent world but a creator who installs reason and the capacity to use it and to go beyond it, into some of His creatures. It involves a creator who installs, in some of His creatures, the capacity to go beyond the world, toward that which shows itself but cannot be uttered in propositions. Providence, non-propositional intellectual apprehension and happiness are manifestations of one and the same thing, in Maimonides.

To summarize, the person who fulfils the Wittgensteinian ideal sees the world sub specie aeterni, sees it rightly, is the one who, for Maimonides, transcends the world; he is guarded against harm and enjoys God's providence to the fullest. The capacity for liberation or salvation is a perceptual capacity. It does not produce propositional knowledge nor is it the direct outcome of propositional knowledge. For both Maimonides and Wittgenstein, the life of knowledge involves "illuminating nonsense", incommunicable "knowledge", a mystical mode of contemplation.

I have so far emphasized the similarities between Maimonides and Wittgenstein. I would like to end with a few brief comments about some of the differences between them. It is on account of these differences that we may conclude that, despite appearances, two fundamentally different conceptions of the sublime and two different models of the "mystical life" are established by Maimonides and by the early Wittgenstein.

\section{REFERRING TO GOD}

In chapter 61 of the Guide, Maimonides appears to distinguish between sense and reference. After insisting that we can neither understand God nor speak about God, Maimonides points out that we can nevertheless refer to God:

All the names of God, may He be exalted, that are to be found in any of the books derive from actions. There is nothing secret in this matter. The only exception is one name: namely Yod, He, Vav, He. This is the name of God, may He be exalted, that has been originated without any derivation, and for this reason, it is called the articulated name. This means that this name gives a clear unequivocal indication of His essence, may He be exalted... 
There can be no doubt about the fact that this great name, which as you know is not pronounced except in the Sanctuary by the sanctified Priests of the Lord and only in the benediction of the Priests and by the High Priest upon the day of fasting, is indicative of a notion with reference to which there is no association between God, may He be exalted, and what is other than He. Perhaps it indicates the notion of a necessary existence, according to the [Hebrew] language, of which we today know only a very scant portion and also with regard to its pronunciation. Generally speaking, the greatness of this name and the prohibition against pronouncing it are due to its being indicative of the essence of Him, may He be exalted, in such a way that none of the created things is associated with Him in this indication. As the Sages, may their memory be blessed have said of it: My name that is peculiar to Me. (I/61, pp. 147-148)

The negative results of the preceding discussion of chapters 51-60 are not the end of the matter. Maimonides maintains that although we cannot know God's nature, nor speak about Him, we can nevertheless refer to Him. It appears that after the appropriate philosophical preparation, we may use the divine name to "gesture at" the sublime, to transpose ourselves by means of language, or to be more precise, by means of the divine name that transcends language, beyond language and beyond this world.

Benor believes that it is by means of negative theology that we can refer to God, in the Guide:

Ipropose that Maimonidesfound in negative theology a method of uniquely identifying the ground of all being, and thus a method of determining the reference of the name 'God', without forming any conception of what God is. ${ }^{20}$

The Guide, however, does not assign any such role to its negative theology. ${ }^{21}$ Reference to God is not made possible by negative theology, which is, after all, of this world, but rather, by God's own revelation

\footnotetext{
${ }^{20}$ Ehud Z. Benor, "Meaning and Reference in Maimonides' Negative Theology", Harvard Theological Review 88/3 (1995), p. 347.

${ }^{21}$ Contrary to Lorberbaum, I maintain that reference to God, in the Guide is not made possible by the philosophical oxymoronic construct "necessary existent" either. For more on Lorberbaum's position, see, Menachem Lorberbaum, Dazzled by Beauty: Theology as Poetics in Hispanic Jewish Culture (Jerusalem: Ben-Zvi Institute, 2011) [in Hebrew].
} 
of His divine name. Maimonides' negative theology is a necessary preliminary philosophical exercise that cleanses the mind, and prepares it for the contemplation of the divine name. It is a therapeutic phase by means of which the mind is cleared of its erroneous ideas about God, and thereby protected against the temptations of idolatry. Such a phase is necessary if we are to be able to combat the ideas or pictures that may occur to us, when we contemplate the divine name. Negative theology, however, does not determine the reference of the name "God". It is God Himself who guarantees the reference of His unique name. ${ }^{22}$ The divine name "which has originated without any derivation" is a trans-linguistic phenomenon; it is a divine revelation, which as such, belongs within the Holy of Holies.

Lorberbaum too, emphasizes the significance of the Tetragrammaton in the Guide:

Maimonides formed a process that removes consciousness and its projections on God from the world; it does so through a critique of the positive attributes ascribed to God, while focusing consciousness on God by means of YHWH, God as a necessary being... ${ }^{23}$

Lorberbaum also maintains that the contemplation of the divine name YHWH culminates in a non-propositional, supra-rational perception or apprehension:

At the climax of the religious process that Maimonides envisages is a moment of enlightenment. The intellectualist mysticism of Maimonides resembles both the Plotinian mysticism and the Sufi mysticism of Rabbi Bahya Ibn Paquda. ${ }^{24}$

Thus, the Maimonidean "via mystica" consists of two components: 1) preliminary philosophical phase that is directed at cleansing the mind of its erroneous, idolatrous ideas about God. This phase involves one's ascent from the lower, idolatrous literary reading of the canonical

${ }^{22} \mathrm{I}$, therefore, also reject Benor's thesis concerning Maimonides' constructivist theology. Given the divine name YHWH, and its role, there is no need for such theology. I am, therefore, committed to a more austere interpretation of Maimonides' rejection of predication.

${ }^{23}$ Lorberbaum, Dazzled by Beauty, p. 121 (my translation).

${ }^{24}$ Ibid. Lorberbaum, therefore, similarly to Blumenthal, takes the Guide's philosophy as "philosophical mysticism". 
texts, into their reading in terms of God's attributes of action, then proceeding to use negative attributes and ending with silence, i.e., with the realization that God's nature cannot be grasped and, that we cannot, therefore, say anything about God, and 2) a positive mystical phase of contemplation of the divine name, $\mathrm{YHWH}$, designed to lead us toward a "moment of enlightenment", toward non-propositional knowledge, toward a super-rational perception or apprehension.

The extraordinary nature of the divine name and its extraordinary contemplative role colour the Maimonidean ladder with transcendentalist colours. It takes the Maimonidean contemplation beyond the Wittgensteinian gestalt awareness of the sublime nature of the contingent. In other words, while the Tractarian "mystical feeling" involves the perception of the world, this world, under its sublime, logically necessary aspect, the Maimonidean mysticism may be said to involve a sensus divinitatis that facilitates, by means of the divine name, our ascent toward that which transcends the world and its logic.

Not only does the Maimonidean "via mystica" offer a different type of liberation, but it also offers experiences of beauty, happiness and safety that go beyond the Tractatus' amor fati. The Maimonidean philosopher/mystic does not merely see the world and every banal and insignificant fact within it as a work of art. He is dazzled by His beauty; not merely by the beauty of the universe. He does not merely cease to bend the world according to his will, nor does he merely cease to will. The Maimonidean philosopher/mystic wills passionately. He bends his whole being toward God; he enjoys the pleasure of the apprehension of God; he is in a state of intense passionate love (III/51). In his pleasure of apprehension, he transcends the contingent world; he transcends illness and death, and finds happiness, for "he is with God and God is with him" (III/51, p. 625).

Thus, while the early Wittgenstein's ladder takes us nowhere, abandoning us into paradox, to run against the walls of our cage (LE, p. 44), against the boundaries of language, unable to reach the sublime, the Maimonidean ladder provides us with a positive way out of our cage: we are able to say "YHWH" even if we cannot say anything about YHWH. We are able to direct ourselves at that which is beyond this world. Our ability to meditate on the divine name introduces 
something "wholly other" into our limited, corporeal lives, something that takes us away from our all-too-human cage.

Whether we are in a cage or somewhere along a ladder that may transpose us beyond the world, toward a "dazzling truth", is a question that this paper cannot answer. ${ }^{25}$

${ }^{25}$ I am grateful to Menachem Lorberbaum for enlightening conversations on Maimonides' intellectual mysticism, for his friendship and support. 